\title{
Requirements regarding dose rate and exposure time for killing of tumour cells in beta particle radionuclide therapy
}

\author{
Jörgen Carlsson¹, Veronika Eriksson¹, Bo Stenerlöw ${ }^{1}$, Hans Lundqvist ${ }^{1}$ \\ 1 Division of Biomedical Radiation Sciences, Department of Oncology, Radiology and Clinical Immunology, Rudbeck Laboratory, \\ Uppsala University, SE-751 85 Uppsala, Sweden
}

Received: 1 November 2005 / Accepted: 26 February 2006 / Published online: 23 May 2006 (C) Springer-Verlag 2006

\begin{abstract}
Purpose: The purpose of this study was to identify combinations of dose rate and exposure time that have the potential to provide curative treatment with targeted radionuclide therapy applying low dose rate beta irradiation.

Methods: Five tumour cell lines, U-373MG and U-118MG gliomas, HT-29 colon carcinoma, A-431 cervical squamous carcinoma and SKBR-3 breast cancer, were used. An experimental model with $10^{5}$ tumour cells in each sample was irradiated with low dose rate beta particles. The criterion for successful treatment was absence of recovery of cells during a follow-up period of 3 months. The initial dose rates were in the range $0.1-0.8 \mathrm{~Gy} / \mathrm{h}$, and the cells were continuously exposed for 1,3 or 7 days. These combinations covered dose rates and doses achievable in targeted radionuclide therapy.

Results: Continuous irradiation with dose rates of $0.2-0.3$ and $0.4-0.6 \mathrm{~Gy} / \mathrm{h}$ for 7 and 3 days, respectively, could kill all cells in each tumour cell sample. These treatments gave total radiation doses of 30-40 Gy. However, when exposed for just $24 \mathrm{~h}$ with about $0.8 \mathrm{~Gy} / \mathrm{h}$, only the SKBR-3 cells were successfully treated; all the other cell types recovered. There were large cell type-dependent variations in the growth delay patterns for the cultures that recovered. The U-118MG cells were most resistant and the U-373MG and SKBR-3 cells most sensitive to the treatments. The HT-29 and A-431 cells were intermediate. Conclusion: The results serve as a guideline for the combinations of dose rate and exposure time necessary to kill tumour cells when applying low dose rate beta irradiation. The shift from recovery to "cure" fell within a narrow range of dose rate and exposure time combinations.
\end{abstract}

Jörgen Carlsson (『)

Division of Biomedical Radiation Sciences,

Department of Oncology, Radiology and Clinical Immunology,

Rudbeck Laboratory,

Uppsala University,

SE-751 85 Uppsala, Sweden

e-mail: Jorgen.Carlsson@bms.uu.se

Tel.: +46-18-4713841, Fax: +48-18-4713432
Keywords: Low dose rate - Nuclear medicine Radionuclide - Radiation effects - Tumour therapy

Eur J Nucl Med Mol Imaging (2006) 33:1185-1195

DOI 10.1007/s00259-006-0109-3

\section{Introduction}

Many types of tumour overexpress cell surface-associated antigens or receptors suitable as targets for radionuclide therapy, and many types of targeting agent have been suggested or are already being applied for such therapy. This therapy is currently employed for lymphomas $[1,2]$ using radiolabelled antibodies and also for neuroendocrine [3-5] and paediatric tumours $[6,7]$ using radiolabelled somatostatin analogues and meta-iodobenzylguanidine (mIBG), respectively. In the majority of these cases, beta emitters such as ${ }^{90} \mathrm{Y},{ }^{131} \mathrm{I}$ and ${ }^{177} \mathrm{Lu}$ have been applied. The results have, so far, essentially shown palliative effects [1, 8-12], and there is hope that combinations of beta particle emitters, e.g. ${ }^{90} \mathrm{Y}$ and ${ }^{177} \mathrm{Lu}$, will improve the therapy results [13].

The cell-killing capacity of low LET radiation, i.e. photons and electrons, is well known when applying high dose rates, typically $0.5-2.0 \mathrm{~Gy} / \mathrm{min}$, as in external radiotherapy $[14,15]$. However, the extensive experimental and clinical knowledge on the effects of external radiotherapy can be deployed to only a limited extent in understanding the effects of radionuclide therapy. A major difference is that the dose rate in radionuclide therapy is at least two orders of magnitude lower than in external radiotherapy [10, 16-19]. The lower dose rate allows for DNA repair and repopulation during the radiation exposure, which is not the case during high dose rate exposures. Basic radiobiological studies have shown that low dose rates, in the range of $0.1-1.0 \mathrm{~Gy} / \mathrm{h}$, give a much lower biological effect (per dose unit) than high dose rates in the range $0.5-2.0 \mathrm{~Gy} / \mathrm{min}[15,17,20,21]$. It is also known that an inverse dose rate effect exists in that dose rates of 0.2 $0.4 \mathrm{~Gy} / \mathrm{h}$ can give more cell kill than dose rates in the range $0.7-1.0 \mathrm{~Gy} / \mathrm{h}[15,22]$. 
Only crude estimates can be made from previous experiments to elucidate which combinations of low dose rate and exposure time can cure a metastasis containing, for example, $10^{5}$ cells. Cell survival has most often been analysed after a cell cloning 1-2 weeks after the radiation exposure. For example, a total dose of about 30-50 Gy, given with $0.1-1.0 \mathrm{~Gy} / \mathrm{h}$, seems necessary to decrease the single cell survival probability to $10^{-5}[23,24]$, and thereby give a reasonable chance of killing $10^{5}$ tumour cells. Furthermore, targeted radionuclide therapy is complicated, since it is not enough only to consider the macroscopic dose concept; different cellular and intracellular distributions of radionuclides can give different biological effects although the macroscopic dose is the same [25, 26].

One way to obtain solid information on which combinations of low dose rate and exposure time can give curative treatments with beta particles (which also is low-LET radiation) is, of course, through experiments and clinical trials. In this study we used an experimental model with the criterion that the low dose rate beta radiation must kill all $10^{5}$ tumour cells in a culture dish in order to simulate a successful treatment. The follow-up period was 3 months.

The choice of $10^{5}$ tumour cells is somewhat arbitrary and is based on two arguments. The first is that this number represents a small tumour cell cluster that normally cannot be identified by routine diagnostic procedures such as computed tomography or magnetic resonance imaging (unless the tumour cells cause macroscopic changes in the surrounding normal tissues). Furthermore, this number of tumour cells in most cases does not cause symptoms in the patient. Thus, a cluster of $10^{5}$ tumour cells in a patient can be considered an "occult" or "subclinical" tumour or metastasis. The second argument is more practical, since the presence of $10^{5}$ tumour cells in a normal cell culture dish or flask allows enough space for exponential growth and, at the same time, frequent cell-cell contacts.

Our ambition was not to simulate the dose rate variations in time and space that occur in radionuclide therapy. In the clinical setting, the dose rate varies with time, not only as a consequence of the physical half-life of the radionuclides, but also due to time-dependent changes in their spatial distribution [16, 17, 24, 26, 27]. Factors of importance are ongoing vascularisation processes, variations in vessel wall leakage and changes in blood flow. There are probably also various diffusion and convection conditions in different areas of tumours, resulting in variable penetration properties of the radiolabelled targeting agents. In addition, there might be variations in the expression of target structures on the tumour cells. All these time-dependent factors make it difficult to establish basic and reproducible dose rateresponse relations in vivo.

Our experimental model was designed to give reproducible and controllable irradiation conditions, and we applied a model with a rather long physical half-life ${ }^{32} \mathrm{P}$ sources with $T_{1 / 2}=14.3$ days), giving only a slow decrease in dose rate during the exposures. Relevant dose rates were selected through the amount of radionuclide placed in the irradiation chambers. The exposure times were selected to correspond to the effective half-lives of the radionuclides delivered by targeting agents of different types.

In targeted radionuclide therapy it is, of course, also necessary to consider unwanted side-effects on normal tissues. However, analyses of normal tissue effects were beyond the scope of this study. Hyperradiosensitivity [28, 29] at low doses, bystander effects [30-32] and low dose rate-induced apoptosis $[33,34]$ are all extensively studied processes. Our model allows these processes to work together, but we did not try to study them separately. The overall goal of the study was to find "dose rate-exposure time" relations that could kill all of the exposed $10^{5}$ tumour cells, so that no remaining cells would be observed after 3 months.

\section{Materials and methods}

\section{Irradiation chambers}

The irradiation chambers have been described previously [35], so only a short description is given here. Three identical chambers were used and each was filled with $400 \mathrm{ml}$ distilled water containing 0.74 $2.22 \mathrm{GBq}^{32} \mathrm{P}$. The water was boiled and degassed shortly before adding ${ }^{32} \mathrm{P}$ and filling of the chambers, in order to avoid air bubbles. The beta emitter ${ }^{32} \mathrm{P}$ (orthophosphate) $\left(T_{1 / 2}=14.3\right.$ days) was obtained from Amersham Pharmacia Biotech (Amersham, UK).

The upper area of the chambers, where the cells were exposed to beta particles from ${ }^{32} \mathrm{P}$, was covered with a $0.5-\mathrm{mm}$ thin transparent polycarbonate foil. The radiation protection walls surrounding the side and the bottom of the chambers, as well as the lid above the cell cultures, consisted of 15-mm transparent polycarbonate (Macrolon). ${ }^{32} \mathrm{P}$ could not reach and be incorporated in the cells. The irradiated cells were grown in 3-cm-diameter culture dishes with a plastic bottom thickness of $1 \mathrm{~mm}$. The culture dishes were placed directly on the thin foils above the ${ }^{32} \mathrm{P}$ source. The chambers were kept in cell culture incubators at $37^{\circ} \mathrm{C}$ (Kebo Assab T304GF, Stockholm, Sweden) and supplied with $5 \%$ carbon dioxide. The lid above the cultures had side openings, allowing efficient passage of the incubator atmosphere.

\section{Dosimetry}

The dosimetry has also been described previously [35]. The dose rate for each chamber was controlled by measurements with a thin-walled parallel ion chamber [36]. The ion chamber was calibrated using an external ${ }^{60} \mathrm{Co}$ source with the front wall of the ion chamber at the dose maximum depth, where the dose rate was $0.30 \mathrm{~Gy} / \mathrm{min}$. The ${ }^{60} \mathrm{Co}$ source was calibrated according to national standard procedures accepted for radiotherapy purposes. The thin-walled parallel ion chamber accurately measured the dose independent of dose rate down to at least $0.01 \mathrm{~Gy} / \mathrm{h}$, if corrections were made for "leakage current" in the instrumentation.

The measurements of dose rates were performed with the thinwalled ion chamber placed in cell culture dishes standing on the ${ }^{32} \mathrm{P}$ radiation chambers. This procedure allowed mimicking of the dose rate in the cell environment. All three chambers were measured repeatedly. Measurements were also made with a surface hand detector (RNI 10/R Intensimeter, Nuklex, Uppsala, Sweden), and a calibration curve was constructed to facilitate repeated dose rate determinations during the cell culture periods. 
Tumour cells

The cells used were HT-29 colorectal adenocarcinoma, A-431 cervical squamous carcinoma, SKBR-3 breast cancer, all from the American Type Culture Collection (ATCC), and the two gliomas U-118MG and U-373MG from the Department of Pathology, Uppsala University, Uppsala, Sweden. They were grown in Ham's F-10 medium supplemented with $10 \%$ fetal bovine serum, $2 \mathrm{mmol} / 1 \mathrm{~L}$-glutamine, $100 \mu \mathrm{g} / \mathrm{ml}$ streptomycin and $100 \mathrm{U} / \mathrm{ml}$ penicillin, all components from Sigma AB (Stockholm, Sweden). The cells were normally grown in an incubator of type Galaxy S (LabRum Klimat AB, Stockholm, Sweden), and during the irradiations they were grown in a similar incubator (Kebo Assab T304GF, Stockholm, Sweden). Both incubators were run at $37^{\circ} \mathrm{C}$ and supplied with $5 \%$ carbon dioxide.

The cells in the study were selected for the following reasons. SKBR-3 cells are often studied since they express large amounts of HER2 receptors and are therefore applied in experiments on HER2directed radionuclide targeting, using antibodies or affibody molecules $[37,38]$. A-431 cells express both large amounts of EGFR and also rather large amounts of HER2 and are therefore often studied for radionuclide targeting with both EGF ligands [39] and anti-HER2 antibodies [40]. Both cell types are planned for experimental therapy using beta particle-mediated radionuclide therapy, especially ${ }^{177} \mathrm{Lu}$. The two glioma cell lines also express EGFR [41] to some degree but were, together with the HT-29 cells, selected because they have recently been studied at our laboratory with regard to short-term effects after low dose rate irradiations [35]. It was found that U-373MG cells showed radiation-induced apoptosis, while U-118MG cells did not. The HT-29 cells were intermediate in this respect [35]. Furthermore, U-373MG cells have previously been reported not to show hyperradiosensitivity at low doses, while both U-118MG and HT-29 cells do [28].

\section{Choice of dose rate and exposure time}

In the previous study, with the same ${ }^{32} \mathrm{P}$ chambers, we analysed effects on cells after exposure to initial dose rates of only 0.05 $0.09 \mathrm{~Gy} / \mathrm{h}$ for 7 days [35]. The cells in that study were analysed for effects on cell number, apoptosis and cell cycle block at day 7 of continuous exposure. However, we also allowed cells to continue to grow for longer times in parallel dishes and found that all cultures recovered. Thus, we decided to apply initial dose rates from $0.1 \mathrm{~Gy} / \mathrm{h}$ up to $0.8 \mathrm{~Gy} / \mathrm{h}$ in the present study to have a reasonable chance of "simulating" curative treatment. We could not apply higher dose rates because of regulatory rules limiting the amount of ${ }^{32} \mathrm{P}$ that could be handled in the cell culture laboratory. Furthermore, this dose rate range is the same as that applied in published studies on low dose rate effects [21-23], hyperradiosensitivity and low dose rate [29], and radionuclide treatment of gliomas in vitro [42] and in vivo [43], and actually covers the range up to the highest dose achievable in targeted radionuclide tumour therapy $[10,16,18,27,44]$.

Four cell dishes were placed in each irradiation chamber when the dose rate was as expected and the cells were then kept there for 24, 72 or $168 \mathrm{~h}$ (1, 3 or 7 days). The radiation exposure time was chosen not to be longer than a week, since it is known from numerous articles in the field of radionuclide therapy that the tumour cell retention of radioactivity is generally in the range of some days up to about 1 week (in some cases it is only a few hours). Furthermore, it is well known that the biological half-life of tumour targeting agents (ligands, antibodies and antibody fragments) in the systemic circulation is often shorter than a week (in the case of small ligands, it is only a few hours). Thus, the longest exposure time considered to be realistic was 1 week.

\section{Cell counting}

The medium was removed from the cell dishes and the cells were quickly washed with $0.5 \mathrm{ml}$ trypsin-EDTA $(0.25 \%$ trypsin $/ 0.02 \%$ EDTA solution in PBS, VWR, Stockholm, Sweden) and then incubated with $0.5 \mathrm{ml}$ trypsin-EDTA $\left(37^{\circ} \mathrm{C}, 5 \% \mathrm{CO}_{2}\right)$ until the cells detached. Next, $1.5 \mathrm{ml}$ medium was added to each dish and the cells resuspended to a single cell solution. For cell counting, $19.5 \mathrm{ml}$ PBS ( $\mathrm{pH} 7.4$ ) was added to $0.5 \mathrm{ml}$ cell suspension and an electronic cell counter was used (Coulter Z2, 7-20 $\mu \mathrm{m}$, Beckman Coulter, Stockholm, Sweden).

\section{Cell culture conditions during and after irradiations}

Cells were seeded sparsely in culture dishes (diameter $3.5 \mathrm{~cm}$, surface $9.6 \mathrm{~cm}^{2}$, Nunc, Roskilde, Denmark) a few days before the
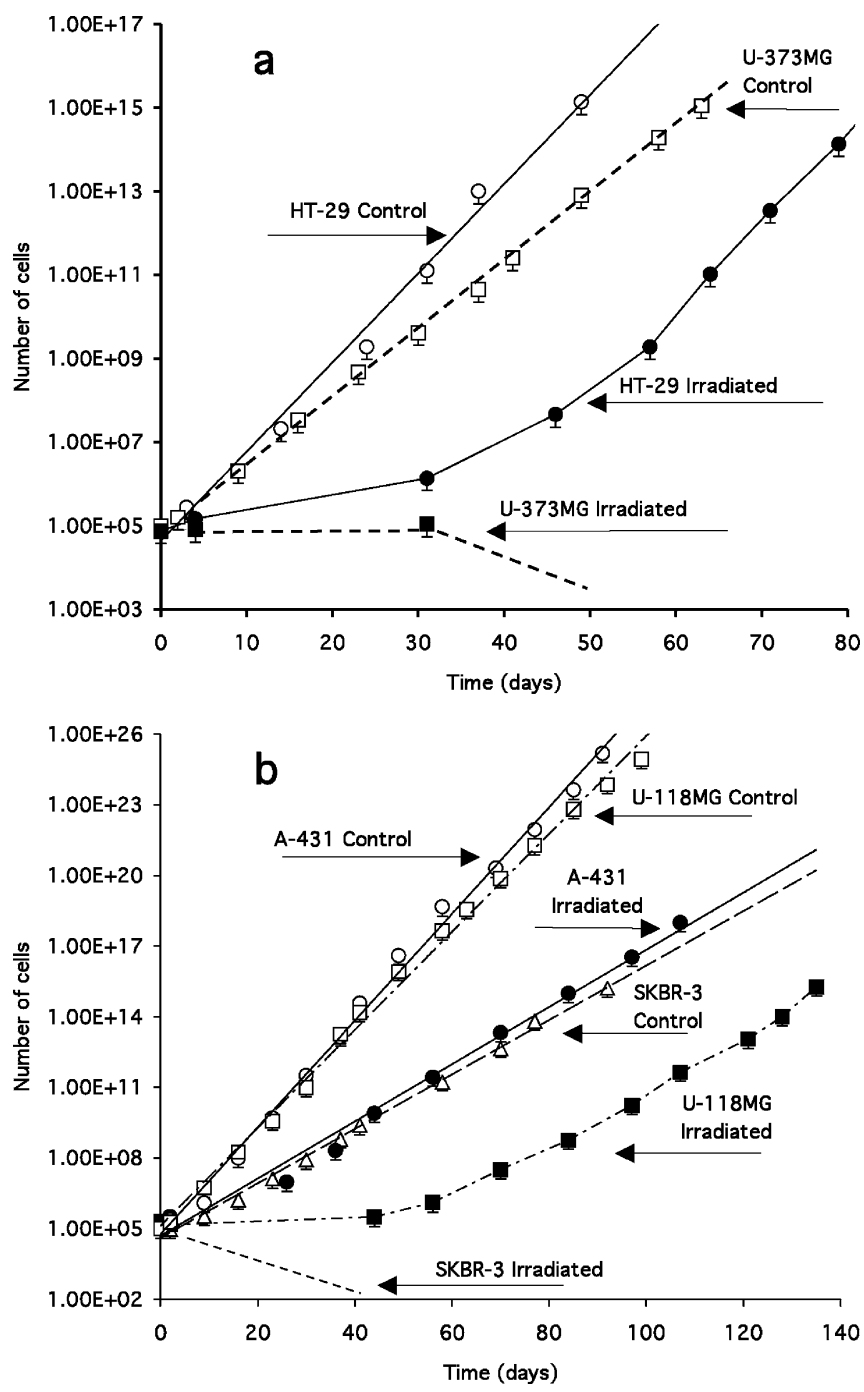

Fig. 1. Examples of cell growth as a function of time after exposure to low dose rate irradiation. a HT-29 and U-373MG cells were exposed to $0.415 \mathrm{~Gy} / \mathrm{h}$ as the initial dose rate and then continuously exposed for $72 \mathrm{~h}$. b A-431, U-118MG and SKBR-3 cells were exposed to $0.806 \mathrm{~Gy} / \mathrm{h}$ as the initial dose rate and then continuously exposed for $24 \mathrm{~h}$. Mean values and maximal variations from four parallel samples are given 

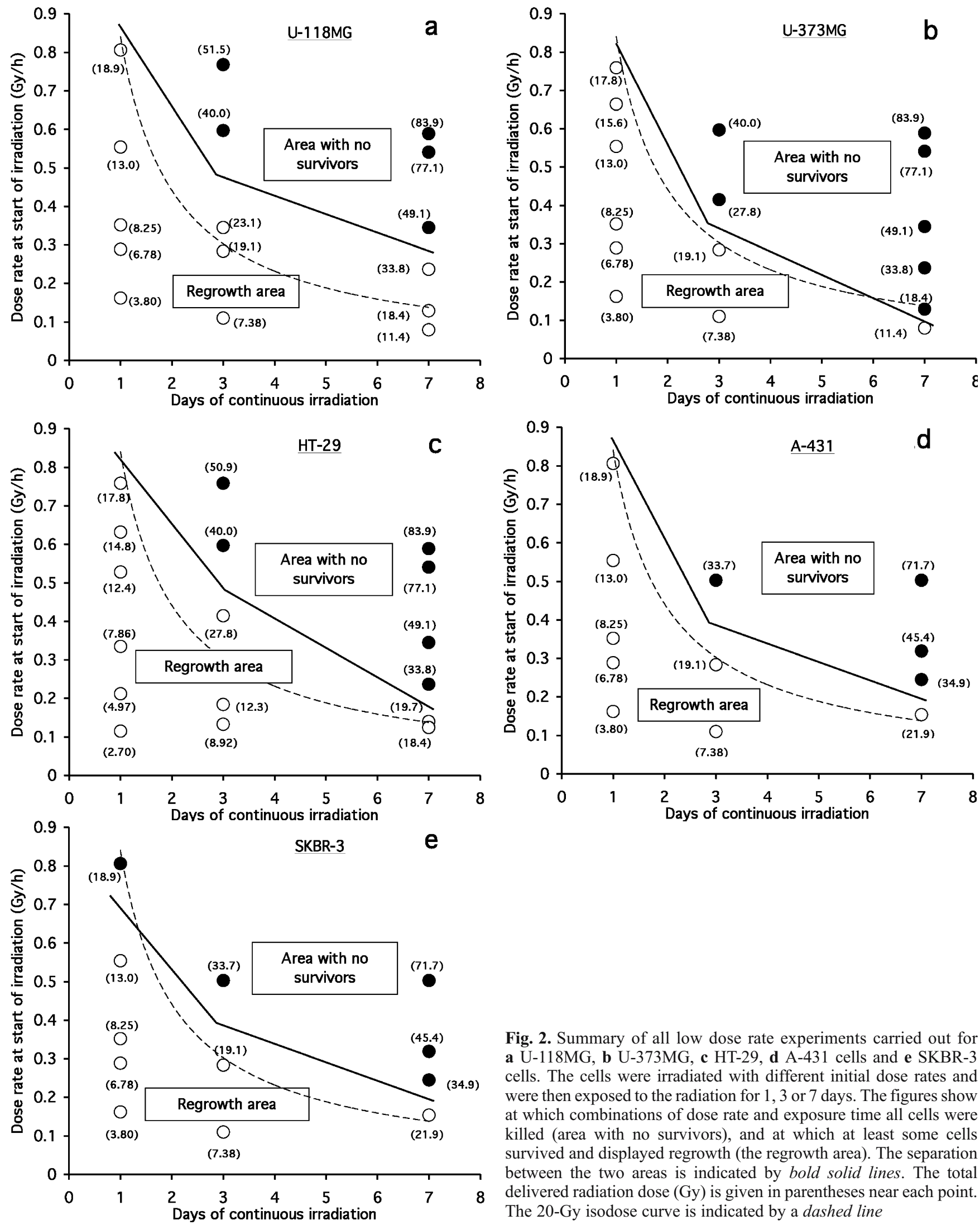

Fig. 2. Summary of all low dose rate experiments carried out for a U-118MG, b U-373MG, c HT-29, d A-431 cells and e SKBR-3 cells. The cells were irradiated with different initial dose rates and were then exposed to the radiation for 1,3 or 7 days. The figures show at which combinations of dose rate and exposure time all cells were killed (area with no survivors), and at which at least some cells survived and displayed regrowth (the regrowth area). The separation between the two areas is indicated by bold solid lines. The total delivered radiation dose (Gy) is given in parentheses near each point. The 20-Gy isodose curve is indicated by a dashed line 
start of the radiation exposure. They were seeded so that each culture dish contained about $10^{5}$ cells at the start of the exposure. The first cell count was made at the start of each experiment, on representative culture dishes. If the cell number was about $10^{5}$ per dish, four other, parallel culture dishes were placed in each of the three irradiation chambers. The irradiated cells were grown in the chambers with unirradiated control dishes placed on a near radiation-shielded shelf in the same incubator. The cells did not reach confluence during the irradiation period. After the radiation exposure, the cells were moved from the irradiation chamber incubator to another incubator and the cell growth was followed for several months. At the first subcultivation after the radiation exposure, the cells were transferred from culture dishes to culture flasks $\left(25 \mathrm{~cm}^{2}\right.$, Nunc, Roskilde, Denmark), and these flasks were then used throughout the growth period. The medium in all culture dishes and flasks was replaced three times a week. Cell counting was in most cases performed once a week, followed by reseeding of $10^{5}$ cells in each new flask.

\section{Growth curves}

The growth curves were constructed as if all cells had been saved at each subcultivation. By calculating how many cells would have been obtained if all cells had been saved, such high cell numbers as $10^{15}$ (Fig. 1a) and even up to $10^{25}$ (Fig. 1b) were obtained. In reality, repeated dilutions were made to keep the number of cells in each culture flask in the range of $10^{5}-10^{6}$, thus allowing for exponential growth. Four parallel flasks were kept for each experiment. In order to analyse the significance of the differences between the groups, $t$ tests were performed.

\section{Cell kill versus regrowth}

The criterion for killing of a cell culture with $10^{5}$ cells was that no living cells could be seen in the phase contrast microscope and that no regrowth was observed after at least 3 months of follow-up, also applying electronic cell counting.

\section{Growth delay}

Growth delay was also analysed after 1,3 or 7 days of continuous low dose rate exposure. The growth curves of the irradiated samples in some cases did not have the same slope as the control curves, so it was not possible to wait and measure growth delay when the recovered cells and the control cells had a similar growth rate. Instead, growth delay was defined as the time it took for the irradiated cells to reach the cell number $10^{10}$ in relation to the time it took for the control cultures to reach this number.

\section{Literature survey}

The Medline-based PubMed database was used to survey effects of targeted radionuclide therapy and of low dose rate therapy.

\section{Results}

\section{Growth curves}

Figure 1 shows examples of growth curves for control cells and cells exposed to continuous low dose rate beta irradiation. In Fig. 1a the initial dose rate was $0.415 \mathrm{~Gy} / \mathrm{h}$ and the exposure time $72 \mathrm{~h}$. After $72 \mathrm{~h}$ the dose rate had decreased to $0.359 \mathrm{~Gy} / \mathrm{h}$, and the exposure gave a total dose of about 27.8 Gy. The irradiated HT-29 cells recovered after irradiation and resumed, after about 50 days, a similar growth rate as the controls. In contrast, the U-373MG cells completely ceased to grow after the same radiation exposure. After more than 30 days, only a few giant cells could be identified in the microscope. They were too few to be counted with the electronic cell counter. However, there was a possibility that at least a few of these cells could grow later, so they were observed (with normal medium changes) for up to 3 months. Nevertheless, no recovery could be observed; instead, the cells disappeared. It was then concluded that the irradiation procedure had killed all U-373MG cells. Thus, the HT-29 cultures survived the treatment, while the U-373MG cells died.

Figure 1b shows examples of growth curves for an initial dose rate of $0.806 \mathrm{~Gy} / \mathrm{h}$ and an exposure time of $24 \mathrm{~h}$. After $24 \mathrm{~h}$ the dose rate had decreased to $0.768 \mathrm{~Gy} / \mathrm{h}$ and the exposure gave a total dose of about $18.9 \mathrm{~Gy}$. The irradiated A431 cells continued to grow, but at a slower rate than the controls. The growth of irradiated U-118MG cells was arrested for up to about 40 days after the treatment. During those 40 days, resting cells were observed in the culture flasks, but there was no sign of growth. After 40 days a few mitotic cells were observed in the phase contrast microscope, and the number of cells was thereafter measured with the electronic cell counter. A clear regrowth was seen after 60 days. However, their growth rate was slower than that of the corresponding controls. The SKBR3 cells looked severely damaged (fragmented, decreasing in number and forming giant cells) some days after the exposure and were too few to be counted with the electronic cell counter. Within 1 month, no surviving cells could be observed in the culture flasks. In this case, too, we continued to control the culture flasks for 3 months (with normal medium changes) and found that there were no remaining cells in these cultures. Thus, A-431 and U-118MG cells survived, while the SKBR-3 cells died.

The conclusions from the examples in Fig. 1a and $\mathrm{b}$ are that four different responses were observed:

- The HT-29 cells recovered to the control growth rate after a growth delay.

- The U-118MG cells recovered after a growth delay but continued to grow at a slower rate than the controls.

- The A-431 cells continued to grow without delay but at a slower rate than the control

- The U-373MG and SKBR-3 cells died. 

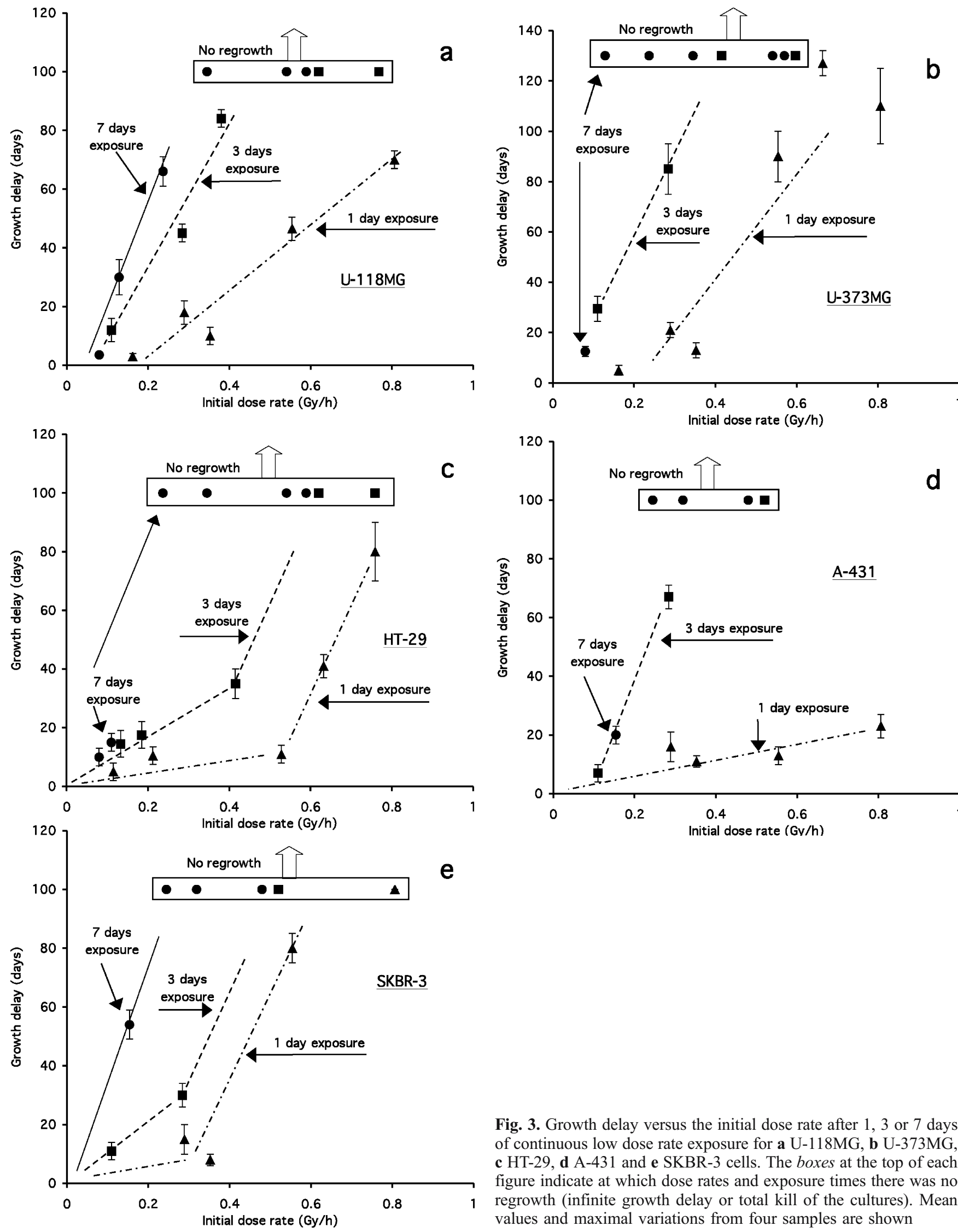

Fig. 3. Growth delay versus the initial dose rate after 1, 3 or 7 days of continuous low dose rate exposure for a U-118MG, b U-373MG, c HT-29, d A-431 and e SKBR-3 cells. The boxes at the top of each figure indicate at which dose rates and exposure times there was no regrowth (infinite growth delay or total kill of the cultures). Mean values and maximal variations from four samples are shown 
Cell kill and regrowth versus dose rate and exposure time

Figure 2 summarises cell-killing and regrowth results from all performed low dose rate experiments. All five analysed cell types were irradiated with different initial low dose rates $(0.1-0.8 \mathrm{~Gy} / \mathrm{h})$ and were continuously exposed for 1 , 3 or 7 days.

Figure 2 parts a-e show a similar and general pattern. When applying 7 days of continuous irradiation, low initial dose rates, about $0.2-0.3 \mathrm{~Gy} / \mathrm{h}$, were enough to kill all cells. When cells were exposed for only 3 days, a dose rate in the order of $0.4-0.6 \mathrm{~Gy} / \mathrm{h}$ was necessary to kill all cells. Only the SKBR-3 cells were killed after 24-h exposure to about $0.8 \mathrm{~Gy} / \mathrm{h}$. As mentioned in Materials and methods, higher dose rates could not be used in these experiments, so we do not know how high the dose rates would have to be during 24-h exposure in order to kill the other cell types. It was found that the regrowth pattern was the same in all four flasks.

However, even if the results looked rather similar and independent of cell type, there were some cell typedependent differences. The U-118MG cells (Fig. 2a) required, during 7 days' exposure, at least about $0.3 \mathrm{~Gy} / \mathrm{h}$ as the initial dose rate to be completely growth inactivated. The U-373MG cells (Fig. 2b) were completely growth inactivated after an initial dose rate of only about $0.15 \mathrm{~Gy} / \mathrm{h}$ and 7 days' exposure. Thus, the U-373MG cells were, in these cases, easier to kill than the U-118MG cells. Considering all cells, it seemed that the U-118MG cells were most resistant and U-373MG and SKBR-3 most sensitive, while A-431 and HT-29 were intermediate.

\section{Cell kill and regrowth versus total dose}

The 20-Gy isodose curve is drawn with a dashed line in Fig. 2a-e. For U-373MG and SKBR-3 cells, at least a total dose of 20 Gy was necessary to prevent regrowth. For HT-29 and A-431 cells an even higher total dose seemed necessary, and for the resistant U-118MG cells it seemed that total doses of at least 40 Gy were necessary to prevent regrowth.

\section{Growth delay as a function of dose rate}

Figure $3 \mathrm{a}-\mathrm{e}$ shows growth delays versus the initial dose rate after 1, 3 or 7 days of continuous low dose rate exposure. The growth delay curves in Fig. 3a show that the radioresistant U-118MG cells had growth delays, after 24-h exposure, which increased slowly as a function of the initial dose rate. A growth delay of 2 months was obtained at about $0.7,0.3$ and $0.2 \mathrm{~Gy} / \mathrm{h}$ after 1,3 and 7 days of continuous exposure, respectively. The growth delay curves for the more radiosensitive U-373MG cells increased more steeply (Fig. 3b), and a growth delay of 2 months was obtained at about 0.5 and $0.2 \mathrm{~Gy} / \mathrm{h}$ after 1 and 3 days of continuous exposure, respectively. Thus, the U-373MG cells were more sensitive than the U-118MG cells also with regard to growth delay.
Both the HT-29 cells (Fig. 3c) and the SKBR-3 cells (Fig. 3e) had a biphasic growth delay curve after 1 day's exposure. The A-431 cells (Fig. 3d) had a slow increase in growth delay as a function of dose rate after 1 day's exposure.

The SKBR-3 cells had a growth delay that increased rather steeply as a function of the dose rate and reached a value of 2 months at about 0.50 and $0.15 \mathrm{~Gy} / \mathrm{h}$ after 1 and 7 days of continuous exposure, respectively (Fig. 3e).

\section{Growth delay as a function of total dose}

The same growth delay data as in Fig. 3a-e are instead plotted as a function of the delivered total dose in Fig. 4a-c, but here, for clarity, without the maximal variations. In all cases, there was a general increasing growth delay as a function of dose. Growth delays in the order of 10 days were obtained for all cells after delivery of total doses in the range 5-15 Gy, independent of whether the dose was given during 1, 3 or 7 days. Delays around 100 days required total doses of about 15-20 Gy when given during 1 day and 25-40 Gy when given during 3 or 7 days, for all cells.

\section{Discussion}

The obtained results can hopefully serve as a guideline for the combinations of dose rate and exposure time necessary to kill tumour cells when applying low dose rate beta irradiation. The shift from regrowth to "cure" (no surviving cells) fell, for each cell type, within a narrow range of combinations.

The U-118MG cells were more resistant to the treatments than the U-373MG and SKBR-3 cells. The A-431 and HT-29 cells showed intermediate resistance. However, the differences between the cell lines were not dramatic, and it can be generally stated that when applying 7 days of continuous irradiation, initial dose rates of about $0.2-0.3 \mathrm{~Gy} / \mathrm{h}$ were enough to kill all cells in the cultures. When exposed for 3 days, an initial dose rate in the order of $0.4-0.6 \mathrm{~Gy} / \mathrm{h}$ was needed. When the cells were exposed for only $24 \mathrm{~h}$ it was not possible to kill all the cells (with the exception of SKBR-3 cells), even if the initial dose rate was as high as about $0.8 \mathrm{~Gy} / \mathrm{h}$.

The studied dose rates are the highest that can be achieved in targeted radionuclide therapy $[10,16,18]$. The total doses achieved after 1, 3 or 7 days' exposure also correspond to the highest achievable doses in targeted radionuclide therapy [16], and most often total doses of no more than 10-20 Gy are obtained in targeting of B-cell lymphomas [19]. However, there are indications from preclinical studies that dramatic "dose amplification" per receptor interaction can be achieved by using effective residualising agents [45].

The obtained dose rates in beta particle-based radionuclide therapy are to a large extent a consequence not only of the amount of radionuclides bound to each tumour cell, but also of the cross-fire effect. This means that radionuclides 

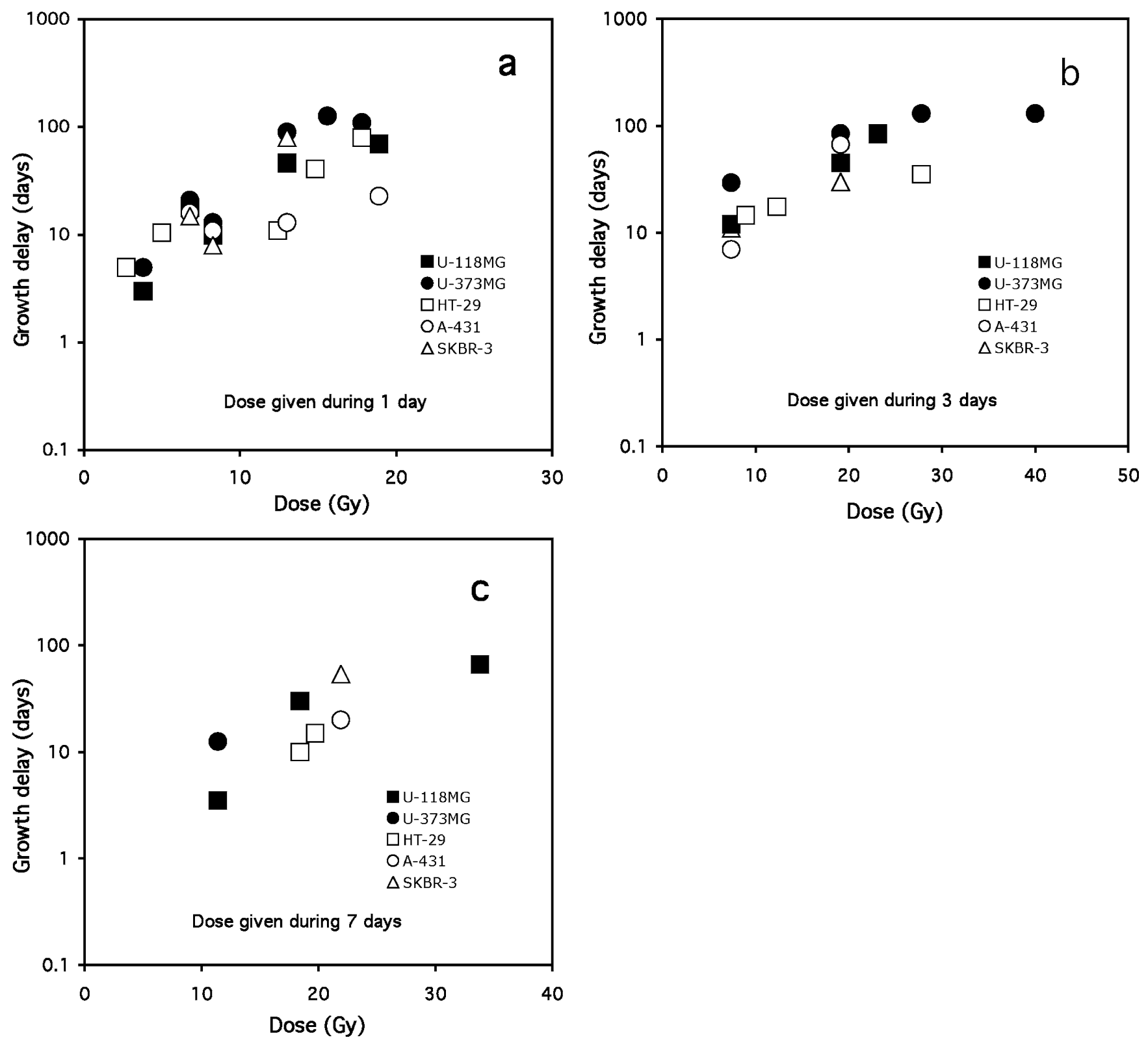

Fig. 4. Growth delay versus total dose after a 1, b 3 or $\mathbf{c} 7$ days of continuous low dose rate exposure for U-118MG, U-373MG, HT-29, A-431 and SKBR-3 cells. The growth delay values are the same as in Fig. 3 but, for clarity, without maximal variations

bound to one cell also irradiate nearby cells owing to the long range of the radiation $[44,46]$. This can increase the dose rate tenfold, and makes it reasonable to assume that dose rates in the range used in our model experiments can be achieved in tumours in patients. The dose rate will be lower for a single tumour cell considering only the radionuclides bound to that cell [25]. Beta particles with a long range will permit rather uniform dose distributions and hopefully deliver therapeutically relevant radiation doses also to non-targeted tumour cells.

Lower dose rates than we applied will probably not lead to curative treatments when beta particles are applied. From the obtained results it is obvious that, at least for the five types of tumour cell tested, we succeeded in finding "dose rate-exposure time" combinations that could distinguish between "cure" (killing of $10^{5}$ tumour cells) and "relapse" (recovery of tumour cells).

There may be cases in which only a fraction of the tumour cells have to be killed directly by radiation, since the remaining tumour cells may be killed through bystander effects [30-32] or other factors (e.g. limited nutrition supply, natural immune response, adjuvant chemo- or immunotherapy). However, our model can be applied under the assumption that $10^{5}$ tumour cells have to be killed by radiation, even if other tumour cells are killed by other means.

When considering radionuclide therapy it is, of course, also important to consider unwanted effects on normal tissues. The tolerance doses for most normal tissues are not known when exposure is to low dose rate irradiation. 
Targeted radionuclide therapy, using, for example, radiolabelled antibodies, fragments of antibodies or various receptor ligands, is expected to result in highly tumourspecific uptake of the therapeutic radionuclides. Thus, for a curative intent it is reasonable to establish the necessary tumour dose rates and exposure times. Another obvious question is which targeting agent should be tried for each type of tumour and, most importantly, whether the required conditions can be achieved without excessively severe side-effects on normal tissues. However, analyses of effects on normal tissues were beyond the scope of this study.

Here we discuss the observed cell type-dependent differences. In a previous study [35] we published data on low dose rate acute effects, using three of the cells in the present study: U-118MG, U-373MG and HT-29. In that study the initial dose rate was only $0.05-0.09 \mathrm{~Gy} / \mathrm{h}$ and the exposure time, 7 days. As would be expected in view of our new data, all cultures did grow after such treatment. It was shown that the U-373MG cells had, at day 7, the most pronounced reduction in cell number owing to a combination of a $\mathrm{G}_{2}$ block and radiation-induced apoptosis. There were surprisingly low reductions in U-118MG and HT-29 cell numbers. U-118MG had a $\mathrm{G}_{2}$ block but no radiationinduced apoptosis. HT-29 had both a $\mathrm{G}_{2}$ block and some radiation-induced apoptosis, but the amount of apoptosis was smaller than for U-373MG cells. Thus, the results from that study indicated the U-373MG cells to be more sensitive than the other two cell lines owing to a higher degree of apoptosis. This is in agreement with the cellkilling results from the present study.

The intrinsic radiosensitivity measured as $\mathrm{S}_{2 \mathrm{~Gy}}$, after exposure to a high dose rate (most often $0.5-2.0 \mathrm{~Gy} / \mathrm{min}$ ) photons has previously been determined for four of our studied cell lines. No determination of $\mathrm{S}_{2 \mathrm{~Gy}}$ for SKBR-3 cells was found in the literature. The results are given in Table $1[28,47-54]$.

There is also a review article on the intrinsic radiosensitivity, measured as cell survival at the dose $2 \mathrm{~Gy}, \mathrm{~S}_{2 \mathrm{~Gy}}$, for 694 human cell lines, of which 271 were from tumours [55]. The tumour cell lines were grouped according to tumour type, and the $\mathrm{S}_{2 \mathrm{~Gy}}$ values for the U-118MG and U-373MG gliomas and the A-431 cervical carcinoma used in this study fell within the expected range of values for the corresponding types of tumour. Thus, these cells can be considered typical for their tumour groups, at least regarding intrinsic radiosensitivity at high dose rate exposure. The HT-29 colorectal carcinoma is an exception, since it seems to be somewhat more radioresistant than most other colorectal carcinomas.

Table 1. Survival at $2 \mathrm{~Gy}$ after exposure to high dose rates

\begin{tabular}{lll}
\hline Cell line & Survival at 2Gy & References \\
\hline U-118MG & $0.44-0.70$ & {$[28],[47]$} \\
U-373MG & $0.60-0.62$ & {$[28],[48],[49]$} \\
HT-29 & $0.55-0.78$ & {$[28],[50],[51],[52],[53],[54]$} \\
A-431 & $\approx 0.52$ & {$[53]$} \\
\hline
\end{tabular}

Considering the values in Table 1, it is clear that there is no relation between $S_{2 G y}$ and the effects of low dose rate irradiations. For example, the U-118MG cells were found to be most radioresistant to a low dose rate, while their $\mathrm{S}_{2 \mathrm{~Gy}}$ values were in the same range as for the other cell lines. The U-373MG cells, which were considered most sensitive to a low dose rate, also had $\mathrm{S}_{2 \mathrm{~Gy}}$ values in the same range.

One possible explanation of the lack of agreement between intrinsic radiosensitivity measured as $\mathrm{S}_{2 \mathrm{~Gy}}$ and the effect of a low dose rate is that there are cell type-dependent differences in repopulation during low dose rate irradiations. Such differences can probably "overshadow" the differences in intrinsic radiosensitivity. Another possible explanation might be cell type-dependent differences in the capacity for low dose rate-induced apoptosis. The latter is supported by our previous study [35], which showed that low dose rate-induced apoptosis was more frequent in U$373 \mathrm{MG}$ cells than in HT-29 cells and that no such apoptosis could be observed for U-118MG cells. Furthermore, it seems as if differences in hyperradiosensitivity (measured at low doses but at a high dose rate) are not of great importance, since the U-118MG and HT-29 cells have been reported to show hyperradiosensitivity, while U-373MG cells do not [28]. Had hyperradiosensitivity been of importance under the exposure conditions in this study, then U-373MG cells should have been more resistant than HT-29 and U-118MG cells.

It has recently been suggested that variations in radiosensitivity at low dose rates are related to the compactness of chromatin [56], but it is not known whether the cells in our study have any differences in this respect. In another recent experimental study, a good therapeutic effect at a low dose rate was reported; in fact, if the total delivered dose was in the range 1-2 Gy, the effect was as good as that achieved at a high dose rate, although the difference in dose rate was nearly three orders of magnitude [57]. This indicates that there are basic radiation biology aspects of low dose rate radiation that have to be analysed in much more detail. A clue to the molecular factors involved came from a recent report showing that activation or inhibition of the DNA damage sensor ATM is of importance [58]. It was found that DNA damage inflicted at a low rate failed to activate ATM; however, if ATM was activated by chloroquine, the cells survived the low dose rate much better.

We conclude that dose rates in the range $0.2-0.3 \mathrm{~Gy} / \mathrm{h}$ are necessary in order to kill $10^{5}$ tumour cells during 1 week's exposure. Higher dose rates, such as $0.4-0.6 \mathrm{~Gy} / \mathrm{h}$ and $>0.8 \mathrm{~Gy} / \mathrm{h}$, are necessary if the exposure times are only 3 days and 1 day, respectively. If, in some cases, a good therapeutic effect cannot be obtained with beta particle radionuclide therapy because of too low dose rates and/or too short exposure times, then repeated (fractionated) treatment is a possibility to improve the result. However, the cellular response to repeated low dose rate exposures has to be analysed in further studies, since there is a risk of radiation-induced changes in the growth pattern of the tumour cells surviving the first exposure, as shown in Fig. 1b. 
Acknowledgements. The authors thank Anders Montelius and Erik Grusell for help with the dosimetry. The Swedish Cancer Society financially supported the study, through grant no 0980-B04-17XCC (040171).

\section{References}

1. Goldenberg DM. Advancing role of radiolabeled antibodies in the therapy of cancer. Cancer Immunol Immunother 2003;52 (5):281-296

2. Wiseman GA, Leigh BR, Erwin WD, Sparks RB, Podoloff DA, Schilder RJ, et al. Radiation dosimetry results from a phase II trial of ibritumomab tiuxetan (Zevalin) radioimmunotherapy for patients with non-Hodgkin's lymphoma and mild thrombocytopenia. Cancer Biother Radiopharm 2003;18(2):165-178

3. Krenning EP, Kwekkeboom DJ, Valkema R, Pauwels S, Kvols LK, De Jong M. Peptide receptor radionuclide therapy. Ann N Y Acad Sci 2004;1014:234-245

4. Pauwels S, Barone R, Walrand S, Borson-Chazot F, Valkema R, Kvols LK, et al. Practical dosimetry of peptide receptor radionuclide therapy with ${ }^{90}$ Y-labeled somatostatin analogs. J Nucl Med 2005;46(Suppl 1):92S-98S

5. Kwekkeboom DJ, Mueller-Brand J, Paganelli G, Anthony LB, Pauwels S, Kvols LK, et al. Overview of results of peptide receptor radionuclide therapy with 3 radiolabeled somatostatin analogs. J Nucl Med 2005;46(Suppl 1):62S-66S

6. Hoefnagel CA. Nuclear medicine therapy of neuroblastoma. Q J Nucl Med 1999;43(4):336-343

7. Yanik GA, Levine JE, Matthay KK, Sisson JC, Shulkin BL, Shapiro B, et al. Pilot study of iodine- ${ }^{131}$ I-metaiodobenzylguanidine in combination with myeloablative chemotherapy and autologous stem-cell support for the treatment of neuroblastoma. J Clin Oncol 2002;20(8):2142-2149

8. DeNardo GL, O'Donnell RT, Kroger LA, Richman CM, Goldstein DS, Shen S, et al. Strategies for developing effective radioimmunotherapy for solid tumors. Clin Cancer Res 1999;5 (10 Suppl):3219s-3223s

9. DeNardo SJ, Williams LE, Leigh BR, Wahl RL. Choosing an optimal radioimmuno-therapy dose for clinical response. Cancer 2002;94(4 Suppl):1275-1286

10. Carlsson J, Forssell Aronsson E, Hietala SO, Stigbrand T, Tennvall J. Tumour therapy with radionuclides: assessment of progress and problems. Radiother Oncol 2003;66(2):107-117

11. Larson SM, Krenning EP. A pragmatic perspective on molecular targeted radionuclide therapy. J Nucl Med 2005;46(Suppl 1): $1 \mathrm{~S}-3 \mathrm{~S}$

12. Sharkey RM, Goldenberg DM. Perspectives on cancer therapy with radiolabeled monoclonal antibodies. J Nucl Med 2005;46 (Suppl 1):115S-127S

13. de Jong M, Breeman WA, Valkema R, Bernard BF, Krenning EP. Combination radionuclide therapy using ${ }^{177} \mathrm{Lu}$ - and ${ }^{90} \mathrm{Y}$-labeled somatostatin analogs. J Nucl Med 2005;46(Suppl 1):13S-17S

14. Steel GG. Basic clinical radiobiology. London: Arnold Publisher and Hodder Headline Group; 1997

15. Hall EJ. Radiobiology for the radiologist, Chap. 5. Philadelphia: Lippincott Williams \& Wilkins; 2000

16. Dillehay LE, Williams JR. Radiobiology of dose-rate patterns achievable in radioimmunoglobulin therapy. Front Radiat Ther Oncol 1990;24:96-103, discussion 121-122

17. Dale RG. Dose-rate effects in targeted radiotherapy. Phys Med Biol 1996;41(10):1871-1884

18. Murtha AD. Radiobiology of low-dose-rate radiation relevant to radioimmunotherapy. Cancer Biother Radiopharm 2000;15 (1):7-14
19. Hernandez MC, Knox SJ. Radiobiology of radioimmunotherapy: targeting CD20 B-cell antigen in non-Hodgkin's lymphoma. Int J Radiat Oncol Biol Phys 2004;59(5):1274-1287

20. Hall EJ. Radiation dose-rate: a factor of importance in radiobiology and radiotherapy. Br J Radiol 1972;45(530):81-97

21. Bedford JS, Mitchell JB. Dose-rate effects in synchronous mammalian cells in culture. Radiat Res 1973;54(2):316-327

22. Mitchell JB, Bedford JS, Bailey SM. Dose-rate effects in mammalian cells in culture III. Comparison of cell killing and cell proliferation during continuous irradiation for six different cell lines. Radiat Res 1979;79(3):537-551

23. Dillehay LE. A model of cell killing by low-dose-rate radiation including repair of sublethal damage, G2 block, and cell division. Radiat Res 1990;124(2):201-207

24. Wong JY, Williams LE, Demidecki AJ, Wessels BW, Yan XW. Radiobiologic studies comparing yttrium-90 irradiation and external beam irradiation in vitro. Int J Radiat Oncol Biol Phys 1991;20(4):715-722

25. Hartman T, Lundqvist H, Westlin JE, Carlsson J. Radiation doses to the cell nucleus in single cells and cells in micrometastases in targeted therapy with ${ }^{131}$ I labelled ligands or antibodies. Int J Radiat Oncol Biol Phys 2000;46(4):1025-1036

26. Howell RW, Neti PV. Modeling multicellular response to nonuniform distributions of radioactivity: differences in cellular response to self-dose and cross-dose. Radiat Res 2005;163 (2):216-221

27. Howell RW, Goddu SM, Rao DV. Design and performance characteristics of an experimental cesium-137 irradiator to simulate internal radionuclide dose rate patterns. J Nucl Med 1997;38(5):727-731

28. Joiner MC, Marples B, Lambin P, Short SC, Turesson I. Lowdose hypersensitivity: current status and possible mechanisms. Int J Radiat Oncol Biol Phys 2001;49(2):379-389

29. Mitchell CR, Folkard M, Joiner MC. Effects of exposure to low-dose-rate ${ }^{60} \mathrm{Co}$ gamma rays on human tumor cells in vitro. Radiat Res 2002;158(3):311-318

30. Prise KM, Folkard M, Michael BD. A review of the bystander effect and its implications for low-dose exposure. Radiat Prot Dosimetry 2003;104(4):347-355

31. Hall EJ. The bystander effect. Health Phys 2003;85(1):31-35

32. Mothersill C, Seymour CB. Radiation-induced bystander effects-implications for cancer. Nat Rev Cancer 2004;4 (2): $158-164$

33. Mirzaie-Joniani H, Eriksson D, Johansson A, Lofroth PO, Johansson L, Ahlstrom KR, et al. Apoptosis in HeLa Hep2 cells is induced by low-dose, low-dose-rate radiation. Radiat Res 2002;158(5):634-640

34. Mirzaie-Joniani H, Eriksson D, Sheikholvaezin A, Johansson A, Lofroth PO, Johansson L, Stigbrand T. Apoptosis induced by low-dose and low-dose-rate radiation. Cancer 2002;94 (4 Suppl):1210-1214

35. Carlsson J, Hakansson E, Eriksson V, Grawe J, Wester K, Grusell E, et al. Early effects of low dose-rate radiation on cultured tumor cells. Cancer Biother Radiopharm 2003;18 (4):663-670

36. Nilsson B, Montelius A. Fluence perturbation in photon beams under nonequilibrium conditions. Med Phys 1986;13(2): 191-195

37. Wikman M, Steffen AC, Gunneriusson E, Tolmachev V, Adams GP, Carlsson J, et al. Selection and characterization of HER2/ neu-binding affibody ligands. Protein Eng Des Sel 2004;17 (5):455-462

38. Steffen AC, Wikman M, Tolmachev V, Adams GP, Nilsson FY, Stahl S, et al. In vitro characterization of a bivalent anti-HER-2 affibody with potential for radionuclide-based diagnostics. Cancer Biother Radiopharm 2005;20(3):239-248 
39. Sundberg AL, Almqvist Y, Orlova A, Blomquist E, Jensen HJ, Gedda L, et al. Combined effect of gefitinib ('Iressa', ZD1839) and targeted radiotherapy with ${ }^{211}$ At-EGF. Eur J Nucl Med Mol Imaging 2003;30(10):1348-1356

40. Nordberg E, Steffen AC, Persson M, Sundberg AL, Carlsson J, Glimelius B. Cellular uptake of radioiodine delivered by trastuzumab can be modified by the addition of epidermal growth factor. Eur J Nucl Med Mol Imaging 2005;32(7):771-777

41. Nister M, Libermann TA, Betsholtz C, Pettersson M, ClaessonWelsh L, Heldin CH, et al. Expression of messenger RNAs for platelet-derived growth factor and transforming growth factoralpha and their receptors in human malignant glioma cell lines. Cancer Res 1988;48(14):3910-3918

42. Marin LA, Smith CE, Langston MY, Quashie D, Dillehay LE. Response of glioblastoma cell lines to low dose rate irradiation. Int J Radiat Oncol Biol Phys 1991;21(2):397-402

43. Zalutsky MR. Current status of therapy of solid tumors: brain tumor therapy. J Nucl Med 2005;46(Suppl 1):151S-156S

44. Essand M, Gronvik C, Hartman T, Carlsson J. Radioimmunotherapy of prostatic adenocarcinomas: effects of ${ }^{131}$ I-labelled E4 antibodies on cells at different depth in DU 145 spheroids. Int J Cancer 1995;63(3):387-394

45. Sundberg AL, Blomquist E, Carlsson J, Steffen AC, Gedda L. Cellular retention of radioactivity and increased radiation dose. Model experiments with EGF-dextran. Nucl Med Biol 2003;30 (3):303-315

46. O'Donoghue JA, Bardies M, Wheldon TE. Relationships between tumor size and curability for uniformly targeted therapy with beta-emitting radionuclides. J Nucl Med 1995;36 (10):1902-1909

47. Nilsson S, Carlsson J, Larsson B, Ponten J. Survival of irradiated glia and glioma cells studied with a new cloning technique. Int J Radiat Biol Relat Stud Phys Chem Med 1980;37(3):267-279

48. Skarsgard LD, Skwarchuk MW, Wouters BG, Durand RE. Substructure in the radiation survival response at low dose in cells of human tumor cell lines. Radiat Res 1996;146(4): 388-398
49. Short SC, Mitchell SA, Boulton P, Woodcock M, Joiner MC. The response of human glioma cell lines to low-dose radiation exposure. Int J Radiat Biol 1999;75(11):1341-1348

50. Fertil B, Malaise EP. Inherent cellular radiosensitivity as a basic concept for human tumor radiotherapy. Int J Radiat Oncol Biol Phys 1981;7(5):621-629

51. Deacon J, Peckham MJ, Steel GG. The radioresponsiveness of human tumours and the initial slope of the cell survival curve. Radiother Oncol 1984;2(4):317-323

52. Frykholm G, Glimelius B, Richter S, Carlsson J. Heterogeneity in antigenic expression and radiosensitivity in human colon carcinoma cell lines. In Vitro Cell Dev Biol 1991;27A(12): 900-906

53. Warenius HM, Browning PG, Britten RA, Peacock JA, Rapp UR. C-raf-1 proto-oncogene expression relates to radiosensitivity rather than radioresistance. Eur J Cancer 1994;30A (3):369-375

54. Wouters BG, Sy AM, Skarsgard LD. Low-dose hypersensitivity and increased radioresistance in a panel of human tumor cell lines with different radiosensitivity. Radiat Res 1996;146 (4):399-413

55. Deschavanne PJ, Fertil B. A review of human cell radiosensitivity in vitro. Int J Radiat Oncol Biol Phys 1996;34(1):251-266

56. Chapman JD. Single-hit mechanism of tumour cell killing by radiation. Int J Radiat Biol 2003;79(2):71-81

57. Verwijnen S, Capello A, Bernard B, van den Aardweg G, Konijnenberg M, Breeman W, et al. Low-dose-rate irradiation by ${ }^{131}$ I versus high-dose-rate external-beam irradiation in the rat pancreatic tumor cell line CA20948. Cancer Biother Radiopharm 2004;19(3):285-292

58. Collis SJ, Schwaninger JM, Ntambi AJ, Keller TW, Nelson WG, Dillehay LE, et al. Evasion of early cellular response mechanisms following low level radiation-induced DNA damage. J Biol Chem 2004;279(48):49624-49632 